\title{
Postoperative Complications in Breast Reconstruction With Porcine Acellular Dermis and Polypropylene Meshes in Subpectoral Implant Placement
}

\author{
KATHARINA SCHÜLER ${ }^{1}$, STEFAN PAEPKE ${ }^{2}$, THOMAS KOHLMANN ${ }^{3}$, ZAHER ALWAFAI ${ }^{4}$, \\ FLORIAN NAWROTH ${ }^{4}$, MAREK ZYGMUNT ${ }^{4}$ and RALF OHLINGER ${ }^{4}$ \\ ${ }^{1}$ Municipal Hospital Brandenburg, Teaching Hospital of the Medical School of Brandenburg, \\ Clinic for Urology and Pediatric Urology, Brandenburg an der Havel, Germany; \\ ${ }^{2}$ Breast Center, Rechts der Isar Hospital Technical University of Munich, Munich, Germany; \\ ${ }^{3}$ University Medicine Greifswald, Institute for Community Medicine, Greifswald, Germany; \\ ${ }^{4}$ Interdisciplinary Breast Center, Clinic and Polyclinic for Gynecology and Obstetrics, \\ University Medicine Greifswald, Greifswald, Germany
}

\begin{abstract}
Aim: This research compares postoperative complication rates with Strattice ${ }^{T M}, \operatorname{SERAGYN}{ }^{\circledR} B R$, and TiLOOP ${ }^{\circledR}$ Bra interposition devices for subpectoral implant placement after skin or nipple sparing mastectomy. Patients and Methods: 188 breast reconstructions in 157 patients after primary $(n=96)$, secondary $(n=71)$, or prophylactic $(n=21)$ surgery were analyzed regarding major and minor complications. Results: With acellular dermal matrix (ADM) Strattice ${ }^{T M}, 27.5 \%$ major and $27.5 \%$ minor complications occurred. Implant loss rates were $27.3 \%$ in primary and $30.8 \%$ in secondary reconstructions. With SERAGYN ${ }^{\circledR}$ BR, $11.1 \%$ major and 13,0\% minor complications occurred. Implant losses $(6.1 \%)$ occurred exclusively in primary reconstructions. With TiLOOP ${ }^{\circledR}$ Bra, $14.9 \%$ major and $9.6 \%$ minor complications occurred. Implant loss rates were $7.7 \%$ in primary and $7.1 \%$ in secondary reconstructions. Conclusion: ADM was associated with high complication rates in primary and secondary reconstructions. Low complication rates were seen with mesh interposition devices in primary, secondary, and prophylactic reconstructions.
\end{abstract}

This article is freely accessible online.

Correspondence to: Katharina Schüler, Municipal Hospital Brandenburg, Teaching Hospital of the Medical School of Brandenburg, Clinic for Urology and Pediatric Urology, Hochstraße 29, 14770 Brandenburg an der Havel, Germany. Tel: +49 1717095540,e-mail: k.schueler.ks@googlemail.com

Key Words: Breast reconstruction, breast cancer, acellular dermal matrix, mesh, titanium-coated, partially absorbable, Strattice ${ }^{\mathrm{TM}}$, SERAGYN ${ }^{\circledR}$ BR, TiLOOP ${ }^{\circledR}$ Bra.
Despite the introduction of new and improved therapeutic concepts in breast cancer treatment, a mastectomy is unavoidable in approximately $30 \%$ of breast carcinomas (1). In the absence of contraindications and with the patient's consent, either a nipple-sparing (NSM) or skin sparing mastectomy (SSM) of the affected breast should be performed. Immediate breast reconstruction yields a high patient satisfaction rate and its use in surgical cancer therapy is steadily increasing (2-5). In surgical breast reconstruction, the pectoralis major muscle is the essential muscle for the formation of an implant pocket, but its dimension is shortened by subpectoral implant insertion, making the use of synthetic mesh or ADM essential (6). While the term primary breast reconstruction describes the immediate reconstruction of the ablated breast after mastectomy in the same surgical session, secondary reconstruction refers to later reconstruction of a breast after ablation or expander insertion due to sparse skin material and/or a weak pectoral skin that cannot ensure sufficient implant coverage. Prophylactic mastectomy can be performed to reduce the risk of disease in cases of BRCA1 or BRCA2 mutations (7).

Despite great intra- and postoperative diligence, the postoperative outcome and risk of complications can be affected by patient-specific factors (age, weight, breast size, previous diseases, nicotine consumption) and therapeutically required measures [i.e., radiotherapy (RTX)]. The most frequently described complications in surgical breast reconstruction are seromas, wound healing disorders, suture dehiscence, infections, necroses, revision surgery and even implant loss; the average complication frequencies reported in the literature range from $6 \%$ to $14 \%$ (8-13). These complications are classified as major or minor. Major complications are defined as complications for which 
conservative treatment is not sufficient, which require surgical intervention and include revisions and explantations (reconstructive failure). Minor complications can be successfully treated conservatively without further surgical intervention (14).

The risk factors for postoperative complications or reconstructive failures assessed in our study, as in the literature, were RTX, nicotine abuse, body mass index (BMI) outside of normal limits and diabetes mellitus (Table I) (8-13, 15, 16). RTX was categorized as preoperative or postoperative. The time between preoperative RTX and breast reconstruction was at least 6 months; for the majority of the patients included in this study it was between 1.5 and 5 years.

This monocentric, retrospective study investigated complication rates occurring with the dermal matrix Strattice ${ }^{\mathrm{TM}}$, the partially absorbable synthetic mesh SERAGYN ${ }^{\circledR}$ BR, and the titanium-coated mesh TiLOOP ${ }^{\circledR}$ Bra in breast reconstructions with subpectoral implant placement, and how these rates were influenced by risk factors and the type of reconstruction. As, with the exception of Eichler et al. (17), no comparative study of complication rates with the above-mentioned interposition devices is available, this study aimed to compare complication rates to add to the knowledge base required for individualized treatment decisions regarding the choice of a mesh or an ADM.

\section{Patients and Methods}

Implant/mesh types. The Allergan company, Dublin, Ireland (at the time of data collection, the company name was LifeCell Corp. Branchburg, NJ, USA), offers the Strattice ${ }^{\mathrm{TM}}$ tissue matrix composed of porcine source cell clusters in which all cellular elements are removed while maintaining an intact matrix with biochemical components. This porcine acellular dermis (PADM) is designed to enable soft tissue healing through rapid neovascularization and cell regeneration, aiming to provide permanent support, skin lining and repair through endogenously induced tissue restructuring (18-22). The SERAGYN ${ }^{\circledR}$ BR mesh from Serag Wiessner (Naila, Germany) is a bicomponent mesh made of polypropylene and absorbable polyglycolic acid. The outer mesh layer is absorbed by the body after approximately 120 days, so that only 6 individual polypropylene filaments remain permanently in the breast and the amount of foreign material is reduced. The TiLOOP ${ }^{\circledR}$ Bra from pfm medical (Cologne, Germany) is a titanium-coated hydrophilic monofilament polypropylene mesh. This interposition device remains unchanged in the patient's breast. The titanium oxide is intended to reduce the rate of inflammation and thus limit the rate of late complications.

What all materials have in common is the formation of a soft implant capsule with a smooth inner surface, which should result in the best possible prosthesis coverage. Although using ADM and synthetic meshes offers many advantages, there are also some risks associated with their use, including postoperative complications such as seroma, hematoma, infection, skin necrosis, or implant loss resulting from postoperative complications (8-11, 23-29). Anatomical implants from Allergan, Mentor (Irvine, CA, USA), POLYTECH (Dieburg, Germany) and Sebbin (Boissy-I'Aillerie, France) were used in the breast reconstructions that were the focus of this study.
Study protocol. Data were collected and analyzed in accordance with the Declaration of Helsinki. The study protocol was reviewed by an ethics committee, which issued a favorable opinion on the preparation of this work. A retrospective data analysis was done for breast reconstructions that involved support by an ADM or mesh after NSM or SSM in 157 female patients with subpectoral implant insertion (31 of them bilateral), which were treated according to surgical gold standards at the Breast Center of the University of Greifswald between November 2010 and June 2015. A total of 188 breasts were reconstructed in a 1 or 2 stage surgical procedure as primary or secondary reconstruction. The PADM Strattice ${ }^{\mathrm{TM}}$ was used in 34 patients (40 breasts), the textile implant SERAGYN ${ }^{\circledR}$ BR in 48 patients (54 breasts) and the titanium-coated polypropylene mesh TiLOOP ${ }^{\circledR}$ Bra in 75 patients (94 breasts). Primary reconstruction was performed in 98 breasts $(52.1 \%, p=0.006)$; secondary reconstruction in 71 breasts $(37.8 \%, p=0.005)$; and prophylactic ablation and subsequent reconstruction in 21 breasts $(11.2 \%, p=0.114)$ (Table II). The median patient age was 50.6 years, the median BMI was 25.6. A BMI $>25$ was noted in $23.5 \%$ of patients, including $39.6 \%$ of patients in the SERAGYN ${ }^{\circledR}$ BR cohort and $42.7 \%$ in the TiLOOP ${ }^{\circledR}$ Bra cohort $(p=0.234)$. The average ablated material weight was $370.6 \mathrm{~g}$ (Table III). All patients were treated with antibiotics for 10 days, thereof $79 \%$ with sultamicillin. Clindamycin was used in case of penicillin intolerance. The drains inserted intraoperatively were removed at a flow rate of $<30 \mathrm{ml} / 24 \mathrm{~h}$.

All relevant patient data were analyzed retrospectively in a pseudonymized manner. The complications were documented to be able to compare the tolerability and success rate of the treatments. The complications were divided into major and minor complications as described in the Introduction.

Patients were divided into underweight $(<18.5)$, overweight $(25$ to 29.5 ), obese (30 to 39.9), and severely obesity ( $>40)$ according to BMI and WHO data. The duration of follow-up was 11.7 months on average (3 weeks to 42 months).

Statistical analyses. Homogeneity tests for categorical variables were performed with Fisher's exact test. For tests of mean differences, ANOVAs for independent samples was used. Pairwise comparison tests (least significant difference) were performed if the $p$-Value was significant. The significance level was set at 0.05 when testing for differences. All analyses were conducted using SPSS version 22 (IBM, Armonk, NY, USA).

\section{Results}

A total of 58 complications occurred, with 27 minor (14.4\%) and 31 major (16.5\%) cases (Table IV). Explantation, including the synthetic mesh or ADM, was performed on 27 implants (14.4\%). Eight implants $(4.3 \%)$ were removed due to R1 status. These were not included in the statistical analysis. Implant loss due to reconstructive failure affected $19(10.1 \%)$ breasts, thereof 11 $(27.5 \%)$ in the Strattice ${ }^{\mathrm{TM}}$ cohort, $2(3.7 \%)$ in the SERAGYN ${ }^{\circledR}$ BR cohort and $6(6.4 \%)$ in the TiLOOP ${ }^{\circledR}$ Bra cohort.

The focus of the assessments was the relation between reconstructive failure and type of reconstruction (Table V). Overall, implant loss occurred in 9 of $96(9.4 \%)$ primary and 10 of $71(14.1 \%)$ secondary reconstructions. In the Strattice ${ }^{\mathrm{TM}}$ cohort, implant loss occurred in 3 of 11 (27.3\%) primary and 
Table I. Distribution of risk factors.

\begin{tabular}{|c|c|c|c|c|c|}
\hline Risk factor & Strattice $^{\mathrm{TM}} \quad(\mathrm{n}=40)$ & SERAGYN ${ }^{\circledR}$ BR $(n=54)$ & $\operatorname{TiLOOP}^{\circledR} \operatorname{Bra}(\mathrm{n}=94)$ & Total $(n=188)$ & $p$-Value \\
\hline $\begin{array}{l}\text { Radiotherapy before reconstructive } \\
\text { surgery }(\mathrm{n}=18)\end{array}$ & $8(23.5 \%)$ & $2(4.2 \%)$ & $18(24 \%)$ & $18(11.5 \%)$ & 0.153 \\
\hline $\begin{array}{l}\text { Radiotherapy after reconstructive } \\
\text { surgery }(n=23)\end{array}$ & $6(17.6 \%)$ & $8(16.7 \%)$ & $23(30.7 \%)$ & $23(14.6 \%)$ & 0.738 \\
\hline Nicotine abuse $(n=40)$ & $9(26.5 \%)$ & $12(25 \%)$ & $19(25.3 \%)$ & $40(25.5 \%)$ & 0.139 \\
\hline BMI $<18,5(n=8)$ & $5(14.7 \%)$ & $0(0 \%)$ & $3(4 \%)$ & $8(5.1 \%)$ & 0.093 \\
\hline BMI 25-29,5 $(n=44)$ & $7(20.6 \%)$ & $15(31.3 \%)$ & $22(29.3 \%)$ & $44(28 \%)$ & 0.021 \\
\hline BMI 30-39 $(n=13)$ & $1(2.9 \%)$ & $3(6.3 \%)$ & $9(12 \%)$ & $13(8.3 \%)$ & 0.018 \\
\hline BMI $>40(n=2)$ & $0(0 \%)$ & $1(2.1 \%)$ & $1(1.3 \%)$ & $2(1.3 \%)$ & 0.607 \\
\hline Total BMI > $25(\mathrm{n}=59)$ & $8(23.5 \%)$ & $19(39.6 \%)$ & $32(42.7 \%)$ & $59(37.6 \%)$ & 0.001 \\
\hline
\end{tabular}

Table II. Distribution of reconstruction types.

\begin{tabular}{|c|c|c|c|c|c|}
\hline & Strattice $^{\mathrm{TM}}(\mathrm{n}=40)$ & SERAGYN ${ }^{\circledR}$ BR $(n=54)$ & TiLOOP $^{\circledR}$ Bra $(n=94)$ & Total $(n=188)$ & $p$-Value \\
\hline Primary reconstruction $(n=96)$ & $11(27.5 \%)$ & $33(61.1 \%)$ & $52(55.3 \%)$ & $96(51.1 \%)$ & 0.006 \\
\hline Secondary reconstruction $(n=71)$ & $26(65 \%)$ & $17(31.5 \%)$ & $28(29.8 \%)$ & $71(37.8 \%)$ & 0.005 \\
\hline Prophylactic reconstruction $(\mathrm{n}=21)$ & $3(7.5 \%)$ & $4(7.4 \%)$ & $14(14.9 \%)$ & $21(11.2 \%)$ & 0.114 \\
\hline Total $(\mathrm{n}=188)$ & $40(100 \%)$ & $54(100 \%)$ & $94(100 \%)$ & $188(100 \%)$ & - \\
\hline
\end{tabular}

Table III. Overall patient characteristics.

\begin{tabular}{|c|c|c|c|c|c|}
\hline & Strattice $^{\mathrm{TM}} \quad(\mathrm{n}=40)$ & SERAGYN ${ }^{\circledR}$ BR $(n=54)$ & TiLOOP ${ }^{\circledR} \operatorname{Bra}(\mathrm{n}=94)$ & Total $(n=188)$ & $p$-Value \\
\hline Age (years) (SD; min-max) & $52.3(5.9 ; 40-69)$ & $53.5(10.7 ; 27-74)$ & $48.1(10.3 ; 23-69)$ & $50.6(9.9 ; 23-74)$ & 0.007 \\
\hline BMI (SD; min-max) & $24.6(4.3 ; 17.2-37.9)$ & $26.2(4.5 ; 20.2-46.9)$ & $25.7(4.4 ; 17.9-37.1)$ & $25.6(4.4 ; 17.2-46.9)$ & 0.296 \\
\hline $\begin{array}{l}\text { Ablated material weight }(\mathrm{g}) \\
\text { (SD; min-max) }\end{array}$ & $295.7(150.3 ; 66-550)$ & $378.6(213 ; 99-926)$ & $399.4(244.2 ; 27-1095)$ & $370.6(224.3 ; 27-1095)$ & 0.288 \\
\hline Implant size (g) (SD; min-max) & $375.6(74 ; 160-405)$ & $408.5(99.3 ; 125-580)$ & $457.3(106 ; 135-580)$ & $424.7(102.3 ; 125-580)$ & 0.088 \\
\hline $\begin{array}{l}\text { Duration of hospitalization (d) } \\
\text { (SD; min-max) }\end{array}$ & $6.4(1.8 ; 4-14)$ & $7.6(2.4 ; 3-12)$ & $7.4(2 ; 3-15)$ & $7.2(2.1 ; 3-15)$ & 0.031 \\
\hline Drain retention $(\mathrm{d})(\mathrm{SD}$; min-max) & $6.2(1.7 ; 3-11)$ & $7.3(3 ; 1-15)$ & $7.3(2.1 ; 3-13)$ & $7.1(2.4 ; 1-15)$ & 0.046 \\
\hline $\begin{array}{l}\text { Total drained volume (ml) } \\
(\mathrm{SD} ; \text { min-max) }\end{array}$ & $409.5(299.7 ; 19-1,750)$ & $505.3(275 ; 10-1,485)$ & $559.7(297.8 ; 40-1,450)$ & $510.2(295.3 ; 1-1,750)$ & 0.048 \\
\hline Follow-up (months) (SD; min-max) & $17.8(0.4 ; 1-42)$ & $11.3(7.1 ; 3-31)$ & $9.2(9 ; 3.29-33)$ & $11.7(9.4 ; 0,69-42)$ & $<0.001$ \\
\hline
\end{tabular}

8 of $26(30.8 \%)$ secondary reconstructions; in the SERAGYN ${ }^{\circledR}$ BR cohort, implant loss occurred exclusively with primary reconstructions ( 2 of 33 breasts, $6.1 \%$ ). In the TiLOOP ${ }^{\circledR}$ Bra cohort, implant loss occurred in 4 of $52(7.7 \%)$ primary and 2 of $28(7.1 \%)$ secondary reconstructions.

The proportion of prophylactic reconstructions by the interposition device was 3 breasts $(7.5 \%)$ for Strattice ${ }^{\mathrm{TM}}, 4$ breasts $(7.4 \%)$ for SERAGYN ${ }^{\circledR}$ BR and 14 breasts $(14.9 \%)$ for TiLOOP ${ }^{\circledR}$ Bra. All prophylactic reconstructions had a complication-free outcome. No statistically significant correlation between the type of reconstruction and reconstructive failure was found (Strattice ${ }^{\mathrm{TM}}, p=1.000$; SERAGYN ${ }^{\circledR}$ BR, $p=0.285$; TiLOOP ${ }^{\circledR}$ Bra, $\left.p=0.312\right)$.

The most frequently documented complications in descending order were: seroma $(11.7 \%)$, revision surgery $(8.0 \%)$, hematoma $(7.6 \%)$, wound infection $(5.9 \%)$, suture dehiscence $(5.3 \%)$, wound healing disorder (4.3\%), postoperative hemorrhage and skin necrosis $(2.7 \%$ each) and abscesses (1.1\%) (Table VI). The association of these complications with risk factors was further investigated. With all 3 interposition devices, preoperative RTX was significantly correlated with the occurrence of seromas $(p=0.026)$, wound 
in vivo $35: 2739-2746(2021)$

Table IV. Distribution of major and minor complications (percentages by individual cohort).

\begin{tabular}{|c|c|c|c|c|c|}
\hline & Strattice $^{\mathrm{TM}} \quad(\mathrm{n}=40)$ & SERAGYN ${ }^{\circledR}$ BR $(n=54)$ & TiLOOP $^{\circledR} \operatorname{Bra}(\mathrm{n}=94)$ & Total $(n=188)$ & $p$-Value \\
\hline Major complications $(n=31)$ & $11(27.5 \%)$ & $6(11.1 \%)$ & $14(14.9 \%)$ & $31(16.5 \%)$ & 0.005 \\
\hline Minor complications $(n=27)$ & $11(27.5 \%)$ & $7(13 \%)$ & $9(9.6 \%)$ & $27(14.4 \%)$ & 0.3679 \\
\hline
\end{tabular}

Table V. Implant loss in relation to reconstruction type (percentages by total patient numbers with the respective reconstruction type).

\begin{tabular}{|c|c|c|c|c|c|}
\hline Interposition device & $\begin{array}{l}\text { Implant loss } \\
\quad(\mathrm{n}=19)\end{array}$ & $\begin{array}{l}\text { Primary reconstruction } \\
\qquad(\mathrm{n}=96)\end{array}$ & $\begin{array}{l}\text { Secondary reconstruction } \\
\qquad(\mathrm{n}=71)\end{array}$ & $\begin{array}{l}\text { Prophylactic reconstruction } \\
\qquad(\mathrm{n}=21)\end{array}$ & $p$-Value \\
\hline Strattice $^{\mathrm{TM}} \quad(\mathrm{n}=40)$ & $11(27.5 \%)$ & 3 of $11(27.3 \%)$ & 8 of $26(30.8 \%)$ & 0 of $3(0 \%)$ & 1.000 \\
\hline SERAGYN ${ }^{\circledR}$ BR $(n=54)$ & $2(3.7 \%)$ & 2 of $33(6.1 \%)$ & 0 of $17(0 \%)$ & 0 of $4(0 \%)$ & 0.285 \\
\hline TiLOOP $^{\circledR} \operatorname{Bra}(\mathrm{n}=94)$ & $6(6.4 \%)$ & 4 of $52(7.7 \%)$ & 2 of $28(7.1 \%)$ & 0 of $14(0 \%)$ & 0.312 \\
\hline
\end{tabular}

Table VI. Distribution of complications.

\begin{tabular}{|c|c|c|c|c|c|}
\hline & Strattice $^{\mathrm{TM}}(\mathrm{n}=40)$ & SERAGYN ${ }^{\circledR}$ BR $(n=54)$ & TiLOOP $^{\circledR}$ Bra $(\mathrm{n}=94)$ & Total $(n=188)$ & $p$-Value \\
\hline Seroma $(n=22)$ & $11(27.5 \%)$ & $7(13 \%)$ & $4(4.3 \%)$ & $22(11.7 \%)$ & 0.001 \\
\hline Hematoma $(n=12)$ & $3(7.5 \%)$ & $4(7.4 \%)$ & $5(5.3 \%)$ & $12(7.6 \%)$ & 0.837 \\
\hline Wound healing disorder $(\mathrm{n}=8)$ & $3(7.5 \%)$ & $1(1.9 \%)$ & $4(4.2 \%)$ & $8(4.3 \%)$ & 0.422 \\
\hline Secondary hemorrhage $(n=5)$ & $0(0 \%)$ & $2(4.2 \%)$ & $3(3.2 \%)$ & $5(2.7 \%)$ & 0.491 \\
\hline Suture dehiscence $(n=10)$ & $5(12.5 \%)$ & $1(1.9 \%)$ & $4(4.3 \%)$ & $10(5.3 \%)$ & 0.018 \\
\hline Wound infection $(n=11)$ & $2(5.9 \%)$ & $2(3.7 \%)$ & $7(9.3 \%)$ & $11(5.9 \%)$ & 0.625 \\
\hline Skin necrosis $(n=5)$ & $2(5 \%)$ & $0(0 \%)$ & $3(3.2 \%)$ & $5(2.7 \%)$ & 0.298 \\
\hline Abscess $(n=2)$ & $1(2.5 \%)$ & $0(0 \%)$ & $1(1.1 \%)$ & $2(1.1 \%)$ & 0.505 \\
\hline Revision surgery $(\mathrm{n}=15)$ & $2(5 \%)$ & $5(9.3 \%)$ & $8(7.4 \%)$ & $15(8 \%)$ & 0.659 \\
\hline Implant loss/reconstructive failure $(n=19)$ & $11(27.5 \%)$ & $2(3.7 \%)$ & $6(6.4 \%)$ & $19(10.1 \%)$ & 0.000 \\
\hline
\end{tabular}

healing disorders $(p=0.023)$, wound infections $(p=0.001)$ and implant losses $(p<0.001)$. Patients with preoperative RTX had higher frequencies of implant losses in all 3 cohorts. Among the total of 19 implant losses, 8 cases were associated with preoperative RTX, 2 cases with postoperative and 9 cases occurred without RTX. Preoperative RTX was statistically significantly associated with reconstructive failure $(p<0.001)$. Postoperative RTX was not significantly related to reconstructive failure $(p=0.105)$. Overall, diabetic patients had a higher frequency of clinically evident seroma postoperatively $(p=0.015)$. There was no statistically significant association between the type of reconstruction and postoperative complications for any interposition device (Strattice ${ }^{\mathrm{TM}}$, $p=1.000 ;$ SERAGYN ${ }^{\circledR}$ BR, $p=0.285$; TiLOOP $^{\circledR}$ Bra, $p=0.312$ ).

\section{Discussion}

In the literature, the use of synthetic meshes and PADM together with silicone implants is described as having a low postoperative complication rate, high patient acceptance and satisfaction, and a low incidence of postoperative morbidity $(31,31)$. For this reason, a comparison between acellular dermal matrices and the already established meshes is useful in order to guide the individual product choice for affected patients (32). Preliminary guidance is available from the retrospective comparison of the synthetic meshes TiLOOP ${ }^{\circledR}$ Bra and SERAGYN ${ }^{\circledR}$ BR undertaken by Eichler et al (17). The complication rates reported for the titanium-coated mesh used in that study (major: $8.3 \%$, minor: $8.9 \%$ ) and SERAGYN ${ }^{\circledR}$ BR (major: $3.9 \%$, minor: $18 \%$ ) are readily comparable with our study. On the contrary, some studies published on Strattice ${ }^{\mathrm{TM}}$ report clearly different results than our study regarding revision surgery and implant losses. While the overall complication rate in the Strattice ${ }^{\mathrm{TM}}$ cohort studied here was $27.5 \%$ each for major and minor events, the majority of publications report rates between $6 \%$ and $10 \%$ for both types of complications. These publications have focused primarily on capsular fibrosis and reconstructive failures (8-13). However, it is particularly 
striking that in some publications, such as the study by Salzberg et al. (10), that around $77 \%$ of patients who received an acellular dermis were treated in the context of prophylactic reconstruction $(8,10,11)$. To date, only a few publications have reported a comparably high complication rate in connection with the use of an ADM (33-35): The complication rates published by these authors are comparable to the results of our study, ranging from approximately $20 \%(8,35)$ to $30 \%$ $(33,36)$ and include seroma, infection, and skin necrosis. The results reported by $\mathrm{Ng}$ et al. (36) on the postoperative outcome in patients treated with RTX and Strattice ${ }^{\mathrm{TM}}$, showed a complication rate of $32 \%$, which is also comparable to our study. Frequencies of minor complications with Strattice ${ }^{\mathrm{TM}}$ were above the average of $0 \%$ to $32 \%$ found in the other ADM studies $(34,35,37-39)$. The most common complication reported across publications was seroma formation. In our study, seroma rates in the ADM cohort were markedly higher than in the SERAGYN ${ }^{\circledR}$ BR and TiLOOP ${ }^{\circledR}$ cohorts and also higher than in other publications with reported seroma rates of $<10 \%(9,10,12,23)$. In our study, RTX prior to breast reconstructive surgery was a significant risk factor with regard to postoperative seroma formation.

In our study, risk factors were equally or less common in patients treated with acellular dermis than in patients treated with SERAGYN ${ }^{\circledR}$ BR or TiLOOP ${ }^{\circledR}$ Bra. The percentage of patients with postoperative RTX in the Strattice ${ }^{\mathrm{TM}}$ cohort was almost identical to the SERAGYN ${ }^{\circledR}$ BR cohort and lower than in the TiLOOP ${ }^{\circledR}$ Bra cohort. Preoperative RTX occurred in similar percentages of patients in the Strattice ${ }^{\mathrm{TM}}$ and TiLOOP ${ }^{\circledR}$ Bra cohorts but in a lower percentage of patients in the cohort treated with SERAGYN ${ }^{\circledR}$ BR. The percentage of smokers was similar between cohorts. Concerning the BMI risk factor, the Strattice ${ }^{\mathrm{TM}}$ cohort had the lowest percentage of patients with a BMI $>25$. A notable difference was found with regard to the type of reconstruction: the majority of breasts treated with SERAGYN ${ }^{\circledR}$ BR or TiLOOP ${ }^{\circledR}$ Bra received primary reconstruction while the majority of breasts treated with Strattice ${ }^{\mathrm{TM}}$ received secondary reconstruction. Evidence from other studies suggests that the type and timing of reconstruction and whether breast reconstruction was performed in the context of cancer therapy has an impact on the multifactorial modulated outcome $(15,39-42)$. In our study, no significant association between the type of reconstruction or mastectomy and postoperative complications was found for any interposition device studied.

In the absence of comprehensive data, the PADM has been increasingly used, due to its properties, in patients with thin pectoral skin and after previous surgery and RTX (20). In 2015 , seven years after the marketing authorization of the medical device, the LifeCell company communicated restrictions for the use of this product and set clear indication limits for the first time. These restrictions particularly applied to secondary reconstructions, post- or preoperative
RTX, as well as the following risk factors: obesity, nicotine abuse, diabetes mellitus, immunosuppression, malnutrition and COPD (20, 43). Ng et al. (36) did not see significant differences with Strattice ${ }^{\mathrm{TM}}$ between pre- and postoperative RTX with regard to the postoperative outcome, even though about $75 \%$ of the complications reported in that publication occurred in patients with preoperative RTX. Based on that conclusion, the aforementioned publication weakens the absolute contraindication of RTX before or after Strattice ${ }^{\text {TM }}$ implantation. With $32 \%$, the complication rate documented by $\mathrm{Ng}$ et al. is approximately as high as in our study (36).

Mitchel (44) showed a much lower complication rate of just under $11 \%$ when using Strattice ${ }^{\mathrm{TM}}$ in conjunction with preoperative RTX. The author attributed the low complication rate to intraoperative rinsing of the subpectoral implant pocket and washing of the ADM in an antibiotic solution. In addition, he considered the acellular dermis to be protective against the negative consequences of postoperative RTX, as no complications were documented in patients undergoing postreconstructive RTX in his study (44). In our study, we found strikingly lower rates for overall major complications and for reconstructive failures with the alloplastic materials TiLOOP ${ }^{\circledR}$ Bra and SERAGYN ${ }^{\circledR}$ BR, compared to Strattice ${ }^{\mathrm{TM}}$.

The outcomes reported in our study are generally consistent with other publications $(17,15,24-29,38)$. The rates of revision surgery, which are around $9 \%$ for SERAGYN ${ }^{\circledR}$ BR and $7 \%$ for TiLOOP ${ }^{\circledR}$ Bra, together with the documented reconstructive failures of $3.7 \%$ for SERAGYN ${ }^{\circledR}$ BR and $6.4 \%$ for TiLOOP ${ }^{\circledR}$ Bra, represent a satisfactory outcome that is comparable to the general literature $(16,17,24-26,28,30,38)$. Based on first experiences with the 2 component mesh SERAGYN ${ }^{\circledR}$ BR, Paepke et al. (24) pointed out that any analysis of complications should also consider the underlying oncological intervention, emphasizing that postoperative problems could have less to do with the insertion of foreign material.

An additional influencing factor is the size of the breast: the greater the volume of ablated material, the greater the risk of a postoperative complication. The size of the breast is particularly relevant with regard to revision surgery and reconstructive failures $(16,45)$. In our study, the highest ablated material weight was noted in patients treated with SERAGYN ${ }^{\circledR}$ BR while it was below the average in patients treated with Strattice ${ }^{\mathrm{TM}}$. Patients treated with TiLOOP ${ }^{\circledR}$ Bra were in the middle range $(p=0.288)$ (Table III). Since the breast size correlated with BMI, an increased ablated material weight in our patients should be interpreted as being an equally large risk factor as an overweight or obese BMI. RTX of the thoracic wall remains an established risk factor: In all breast reconstructions with the PADM or one of the mesh alloplastic materials, there is a possible causality between RTX and implant losses as well as wound infections.

However, although our data do not support a statistically significant association between postoperative RTX and 
implant losses, the risk of reconstructive failure after breast reconstruction in conjunction with RTX of the treated area has been confirmed in most of the published literature. The reason for this is the delayed or inhibited revascularization and cell infiltration in the wound area $(8,15,40,42,46,47)$. With regard to the use of TiLOOP ${ }^{\circledR}$ Bra, it has been reported that the outcome is not influenced by RTX (48). Nevertheless, recommendations for implant-based breast reconstruction suggest avoiding a combination with postoperative RTX, regardless of whether mesh, dermis or neither of them is used $(14,49)$. A study by Karsten et al. (50) shows that implantation of Strattice ${ }^{\mathrm{TM}}$ triggers a significant interleukin release in the patient's T and B cells and thus an increased immune response. Another study has demonstrated the proinflammatory effect of ADMs in an animal model (51). Strattice ${ }^{\mathrm{TM}}$ was reported to be associated with the highest incidence of inflammatory reactions compared with other ADMs in several publications $(31,52)$. In contrast to our study, Eichler et al. (17) did not report any significant differences in implant loss rates in a retrospective comparison of synthetic meshes and the human ADMs SurgiMend ${ }^{\circledR}$ and epIflex ${ }^{\circledR}$. On this basis, a trend towards the use of synthetic meshes in clinical practice is observed in the aforementioned study with comparable outcomes but significantly different costs. The majority of breast reconstructions analyzed in our study were associated with few or no complications. In total, $71.8 \%$ of breasts were reconstructed without a postoperative complication.

Our study describes real-world clinical events through a retrospective evaluation of data. However, the impact of our results on the optimization of patient care is rather low. Controlled, randomized, prospective multicenter studies could provide further information for individualized therapy choices in the future.

A low complication rate can be noted with the 2 component mesh SERAGYN ${ }^{\circledR}$ BR and the titanium-coated polypropylene mesh TiLOOP $^{\circledR}$ Bra across all reconstruction procedures analyzed in our study. This contrasts with the high rate of postoperative complications in breast reconstructions associated with the acellular dermis Strattice ${ }^{\mathrm{TM}}$, in particular with secondary breast reconstruction. It should be emphasized that in our study, as in other publications, ADM was used preferentially in secondary reconstructions and in conjunction with RTX. More results are needed, especially in comparing the type of reconstruction together with RTX when using Strattice $^{\mathrm{TM}}$. Nevertheless, if pre- or postoperative RTX is necessary, breast reconstruction with autologous tissue (e.g., TRAM or DIEP flap) should be recommended in accordance with the guidelines instead of mesh- or dermis-supported reconstruction (7). Should the respective patient nevertheless opt for breast reconstruction with mesh or acellular dermis, the increased risk with regard to postoperative complications must be pointed out and explained in detail.

\section{Conflicts of Interest}

Katharina Schüler, Thomas Kohlmann, Zaher Alwafai, Florian Nawroth and Marek Zygmunt have no conflicts of interest to disclose. Stefan Paepke is a consultant of the following companies: pfm medical ag, Cologne, Germany; Novusscientific, Sweden; Triconmed, Germany; Sysmex, Germany; Sysmex, Europe; Neodynamics, Sweden; MBN, Germany; Invitrocue Europe GmBH; Dynamesh, Germany; Scientific grants: RTI Surgical; pfm medical ag; Novusscientific, Sweden; AG, Germany; GBG, Germany. He has supported workshops of: Roche, Grenzach-Whylen; Sysmex, Germany; Philips GmBH; Triconmed, Germany. In the past, he has been a consultant of Serag Wiessner AG ( $<5$ years); KCI ( $>3$ years); DZIG, Berlin ( $<5$ years); Allergan ( $>3$ years). Ralf Ohlinger is a consultant and has supported workshops of pfm medical ag, Cologne, Serag Wiessner AG and KCI in the past.

\section{Authors' Contributions}

Ralf Ohlinger planned the study, recruited the patients, performed the surgery, analyzed the data, wrote and edited the manuscript. Marek Zygmunt planed the study and edited the manuscript. Florian Nawroth edited the manuscript. Zaher Alwafai recruited the patients, performed the surgery and edited the manuscript. Thomas Kohlmann performed the statistical analysis and edited the manuscript. Stefan Paepke analyzed the data, wrote and edited the manuscript. Katharina Schüler collected and analyzed the data, wrote and edited the manuscript, assisted with surgeries.

\section{References}

1 Dieterich M, Reimer T, Stachs A, Dieterich H and Gerber B: Wieviel Haut kann bei der haut- und nippelsparenden Mastektomie gespart werden, ohne das onkologische Risiko zu erhöhen? Teil 1 und 2. gyn (18): 346-352, 434-443, 2013.

2 Gui GPH, Kadayaprath G, Tan SM, Faliakou EC, Choy C, Ward A and A'Hern R: Long-term quality-of-life assessment following one-stage immediate breast reconstruction using biodimensional expander implants: the patient's perspective. Plast Reconstr Surg 121(1): 17-24, 2008. PMID: 18176201. DOI: 10.1097/01.prs.00 00293875.33012 .84

3 Patani N, Devalia H, Anderson A and Mokbel K: Oncological safety and patient satisfaction with skin-sparing mastectomy and immediate breast reconstruction. Surg Oncol 17(2): 97-105, 2008. PMID: 18093828. DOI: 10.1016/j.suronc.2007.11.004

4 Zhang H, Li Y, Moran MS, Haffty BG and Yang Q: Predictive factors of nipple involvement in breast cancer: a systematic review and meta-analysis. Breast Cancer Res Treat 151(2): 239249, 2015. PMID: 25893590. DOI: 10.1007/s10549-015-3385-4

5 Munhoz AM, Montag E, Filassi JR and Gemperli R: Immediate nipple-areola-sparing mastectomy reconstruction: An update on oncological and reconstruction techniques. World J Clin Oncol 5(3): 478-494, 2014. PMID: 25114861. DOI: 10.5306/wjco.v5. i3.478

6 Gabka CJ and Bohmert H: Plastische und rekonstruktive Chirurgie der Brust, chapter: Sofortrekonstruktion der Brust. Thieme Verlag, 2. Auflage, pp. 252-281, 2006.

7 AGO Leitlinie Mammakarzinom, Konsultationsfassung, Stand 12/2020. Available at: https://www.leitlinienprogramm- 
onkologie.de/fileadmin/user_upload/Downloads/Leitlinien/Mam makarzinom_4_0/Version_4.4/LL_Mammakarzinom_Langversio n_4.04.pdf [Last accessed on July 15, 2021]

8 Hille-Betz U, Kniebusch N, Wojcinski S, Henseler H, Heyl V, Ohlinger R, Paepke S, Klapdor R and Krause-Bergmann B: Breast reconstruction and revision surgery for implant-associated breast deformities using porcine acellular dermal matrix: a multicenter study of 156 cases. Ann Surg Oncol 22(4): 1146-1152, 2015. PMID: 25300607. DOI: 10.1245/s10434-014-4098-3

9 Glasberg SB and Light D: AlloDerm and Strattice in breast reconstruction: a comparison and techniques for optimizing outcomes. Plast Reconstr Surg 129(6): 1223-1233, 2012. PMID: 22327891. DOI: 10.1097/PRS.0b013e31824ec429

10 Salzberg CA, Dunavant C and Nocera N: Immediate breast reconstruction using porcine acellular dermal matrix (Strattice $^{\mathrm{TM}}$ ): long-term outcomes and complications. J Plast Reconstr Aesthet Surg 66(3): 323-328, 2013. PMID: 23153519. DOI: 10.1016/j.bjps.2012.10.015

11 Spear SL, Seruya M, Clemens MW, Teitelbaum S and Nahabedian MY: Acellular dermal matrix for the treatment and prevention of implant-associated breast deformities. Plast Reconstr Surg 127(3): 1047-1058, 2011. PMID: 21088648. DOI: 10.1097/PRS.0b013e31820436af

12 Hester TR Jr, Ghazi BH, Moyer HR, Nahai FR, Wilton M and Stokes L: Use of dermal matrix to prevent capsular contracture in aesthetic breast surgery. Plast Reconstr Surg 130(5 Suppl 2): 126S-136S, 2012. PMID: 23096962. DOI: 10.1097/PRS.0b $013 \mathrm{e} 3182605 \mathrm{~d} 18$

13 Spear SL, Sinkin JC and Al-Attar A: Porcine acellular dermal matrix (strattice) in primary and revision cosmetic breast surgery. Plast Reconstr Surg 131(5): 1140-1148, 2013. PMID: 23629094. DOI: 10.1097/PRS.0b013e3182865d0c

14 Lin KY, Blechman AB and Brenin DR: Implant-based, two-stage breast reconstruction in the setting of radiation injury: an outcome study. Plast Reconstr Surg 129(4): 817-823, 2012. PMID: 22456353. DOI: 10.1097/PRS.0b013e31824421d0

15 Dieterich M, Paepke S, Zwiefel K, Dieterich H, Blohmer J, Faridi A, Klein E, Gerber B and Nestle-Kraemling C: Implant-based breast reconstruction using a titanium-coated polypropylene mesh (TiLOOP Bra): a multicenter study of 231 cases. Plast Reconstr Surg 132(1): 8e-19e, 2013. PMID: 23806958. DOI: 10.1097/ PRS.0b013e318290f8a0

16 Machleidt A, Schmidt-Feuerheerd N, Blohmer JU, Ohlinger R, Kueper J, von Waldenfels G, Dittmer S, Paepke S and Klein E: Reconstructive breast surgery with partially absorbable bicomponent Seragyn ${ }^{\circledR}$ BR soft mesh: an outcome analysis. Arch Gynecol Obstet 298(4): 755-761, 2018. PMID: 30083777. DOI: 10.1007/s00404-018-4859-5

17 Eichler C, Schulz C, Thangarajah F, Malter W, Warm M and Brunnert K: A Retrospective head-to-head comparison between TiLoop Bra/TiMesh ${ }^{\circledR}$ and Seragyn ${ }^{\circledR}$ in 320 cases of reconstructive breast surgery. Anticancer Res 39(5): 2599-2605, 2019. PMID: 31092458. DOI: 10.21873/anticanres. 13383

18 Paepke S and Ohlinger R: Plastisch-rekonstruktive mammachirurgie. Indikation, techniken, materialien. Chir Prax 81(1): 281-292, 2016.

19 Connor J, McQuillan D, Sandor M, Wan H, Lombardi J, Bachrach $\mathrm{N}$, Harper $\mathrm{J}$ and $\mathrm{Xu} \mathrm{H}$ : Retention of structural and biochemical integrity in a biological mesh supports tissue remodeling in a primate abdominal wall model. Regen Med 4(2): 185-195, 2009. PMID: 19317639. DOI: 10.2217/17460751.4.2.185
20 Kiechle M, Ettl J, Niemeyer M and Paepke S: Einsatz von azellulärer Dermis (Strattice) in der plastisch-rekonstruktiven Mammachirurgie - eine Kohortenbetrachtung. Senologie Zeitschrift für Mammadiagnostik und -therapie 8(02): A102, 2011. DOI: $10.1055 / \mathrm{s}-0031-1278104$

21 Orenstein SB, Qiao Y, Klueh U, Kreutzer DL and Novitsky YW: Activation of human mononuclear cells by porcine biologic meshes in vitro. Hernia 14(4): 401-407, 2010. PMID: 20145965. DOI: $10.1007 / \mathrm{s} 10029-010-0634-7$

22 Katerinaki E, Zanetto U and Sterne GD: Histological appearance of Strattice tissue matrix used in breast reconstruction. J Plast Reconstr Aesthet Surg 63(12): e840-e841, 2010. PMID: 20650694. DOI: $10.1016 /$ j.bjps.2010.06.033

23 Himsl I, Drinovac V, Lenhard M, Stöckl D, Weissenbacher T and Dian D: The use of porcine acellular dermal matrix in silicone implant-based breast reconstruction. Arch Gynecol Obstet 286(1): 187-192, 2012. PMID: 22382372. DOI: 10.1007/s00404012-2266-X

24 Paepke S, Klein E, Völkel P, Dittmer S, Rezai A, Blohmer J, Harms E, Ohlinger R, Niemeyer M, Paepke D, Bronger H, Krol J and Kiechle M: Einsatz des teilresorbierbaren ZweikomponentenPolypropylen-Vicryl-Meshs (SERAGYN®BR) als Gewebeinterponat in der plastisch-rekonstruktiven Mammachirurgie - erste Erfahrungen. Senologie - Zeitschrift für Mammadiagnostik und -therapie 9(04): 217-222, 2017. DOI: 10.1055/s-0032-1330305

25 Paepke S, Klein E, Ettl J, Bronger H, Paepke D and Kiechle M: Netzunterstützte Techniken in der plastisch- rekonstruktiven Mammachirurgie. Gynäkologische Praxis 36: 691-701, 2012.

26 Dieterich M, Dieterich H, Timme S, Reimer T, Gerber B and Stubert J: Using a titanium-coated polypropylene mesh (TiLOOP(®) Bra) for implant-based breast reconstruction: case report and histological analysis. Arch Gynecol Obstet 286(1): 273276, 2012. PMID: 22366804. DOI: 10.1007/s00404-012-2253-2

27 Rezai M, Strauß S and Kern P: Skin sparing and subcutaneous mastectomy (SSM, SCM) and immediate breast reconstruction (IBR) - updated results of reconstruction with titanium-coated meshes (TiLOOP Bra). Oncoplastic - Seventh European Conference, Milan, 4th December - 7th December, 2013.

28 Rezai M: Skin sparing mastectomy (SSM) and immediate breast reconstruction (IBR -innovating techniques with titanium-coated mesh (TiLOOP Bra). Oncoplastic and Reconstructive Surgery of the Breast, Sixth European Conference, Milan, 14th December - 17th December, 2011.

29 Rulli A, Caracappa D, Castellani E, Arcuri G, Barberini F, Sanguinetti A, Noya G, Pataia E and Covarelli P: Optimizing therapeutic timing in patients undergoing mastectomy through use of the Tiloop ${ }^{\circledR}$ synthetic mesh: single-step surgery. In Vivo 27(3): 383-386, 2013. PMID: 23606695.

30 Thill M, Faridi A, Meiré A, Gerber-Schäfer C, Baumann K, Blohmer JU, Mau C, Tofall S, Nolte E, Strittmatter HJ, Ohlinger $\mathrm{R}$ and Paepke S: Patient reported outcome and cosmetic evaluation following implant-based breast-reconstruction with a titanized polypropylene mesh $\left(\right.$ TiLOOP ${ }^{\circledR}$ Bra): A prospective clinical study in 269 patients. Eur J Surg Oncol 46(8): 14841490, 2020. PMID: 32336622. DOI: 10.1016/j.ejso.2020.04.009

31 Ohlinger R, Alwafai Z, Paepke S, Zygmunt M, Nawroth F, Schüler $K$ and Fröhlich P: Patient quality of life after subpectoral implant-based breast reconstruction with synthetic or biological materials. Anticancer Res 41(6): 3075-3082, 2021. PMID: 34083300. DOI: 10.21873/anticanres.15091 
32 Stevens LA, McGrath MH, Druss RG, Kister SJ, Gump FE and Forde KA: The psychological impact of immediate breast reconstruction for women with early breast cancer. Plast Reconstr Surg 73(4): 619-628, 1984. PMID: 6709743. DOI: 10.1097/00006534-198404000-00018

33 Lardi AM, Ho-Asjoe M, Mohanna PN and Farhadi J: Immediate breast reconstruction with acellular dermal matrix: factors affecting outcome. J Plast Reconstr Aesthet Surg 67(8): 10981105, 2014. PMID: 24927863. DOI: 10.1016/j.bjps.2014.05.020

34 Lohmander F, Lagergren J, Roy PG, Johansson H, Brandberg Y, Eriksen $\mathrm{C}$ and Frisell $\mathrm{J}$ : Implant based breast reconstruction with acellular dermal matrix: Safety data from an open-label, multicenter, randomized, controlled trial in the setting of breast cancer treatment. Ann Surg 269(5): 836-841, 2019. PMID: 30308615. DOI: $10.1097 /$ SLA.0000000000003054

35 Mazari FAK, Wattoo GM, Kazzazi NH, Kolar KM, Olubowale OO, Rogers CE and Azmy IA: The comparison of strattice and surgimend in acellular dermal matrix-assisted, implant-based immediate breast reconstruction. Plast Reconstr Surg 141(2): 283293, 2018. PMID: 29369979. DOI: 10.1097/PRS.00000000 00004018

$36 \mathrm{Ng}$ CE, Pieri A and Fasih T: Porcine acellular dermis-based breast reconstruction: complications and outcomes following adjuvant radiotherapy. Eur J Plast Surg 38(6): 459-462, 2015. PMID: 26635446. DOI: 10.1007/s00238-015-1130-1

37 Israeli R: Complications of acellular dermal matrices in breast surgery. Plast Reconstr Surg 130(5 Suppl 2): 159S-172S, 2012. PMID: 23096966. DOI: 10.1097/PRS.0b013e3182634e62

38 Ohlinger R, Nawroth F, Kohlmann T, Alwafai Z, Schueler K, Zygmunt $\mathrm{M}$ and Paepke S: Retrospective study of radiotherapy impact on the outcome of material-assisted implant-based subpectoral breast reconstruction. Anticancer Res 41(4): 20172024, 2021. PMID: 33813408. DOI: 10.21873/anticanres.14969

39 Reitsamer R, Peintinger F, Klaassen-Federspiel F and Sir A: Prepectoral direct-to-implant breast reconstruction with complete ADM or synthetic mesh coverage - 36-months follow-up in 200 reconstructed breasts. Breast 48: 32-37, 2019. PMID: 31491673. DOI: 10.1016/j.breast.2019.08.002

40 Colwell AS, Damjanovic B, Zahedi B, Medford-Davis L, Hertl $\mathrm{C}$ and Austen WG Jr: Retrospective review of 331 consecutive immediate single-stage implant reconstructions with acellular dermal matrix: indications, complications, trends, and costs. Plast Reconstr Surg 128(6): 1170-1178, 2011. PMID: 22094736. DOI: $10.1097 / \mathrm{PRS} .0 \mathrm{~b} 013 \mathrm{e} 318230 \mathrm{c} 2 \mathrm{f} 6$

41 Salzberg CA, Ashikari AY, Koch RM and Chabner-Thompson E: An 8-year experience of direct-to-implant immediate breast reconstruction using human acellular dermal matrix (AlloDerm). Plast Reconstr Surg 127(2): 514-524, 2011. PMID: 21285756. DOI: 10.1097/PRS.0b013e318200a961

42 Spear SL, Parikh PM, Reisin E and Menon NG: Acellular dermis-assisted breast reconstruction. Aesthetic Plast Surg 32(3): 418-425, 2008. PMID: 18338102. DOI: 10.1007/s00266-0089128-8

43 Dringende Sicherheitsmitteilung der Firma LifeCell Kommerzielle Bezeichnung Strattice Rekonstruktive Gewebematrix FSCA-Kennung: EVAL-2015-002 Art der Maßnahme: Sicherheitshinweis, 16. Juli 2015. Available at https://www.bfarm.de/SharedDocs/Kundeninfos/DE/11/2016/041 16-15_kundeninfo_de.pdf?_blob=publicationFile\&v=5 [Last accessed on July 15, 2021]
44 Mitchell RE: Porcine acellular dermis-assisted breast reconstruction: influence of adjuvant radiotherapy on complications and outcomes. Plast Reconstr Surg Glob Open 1(8): e77, 2013. PMID: 25289272. DOI: 10.1097/GOX.0000000000000020

45 Lanier ST, Wang ED, Chen JJ, Arora BP, Katz SM, Gelfand MA, Khan SU, Dagum AB and Bui DT: The effect of acellular dermal matrix use on complication rates in tissue expander/implant breast reconstruction. Ann Plast Surg 64(5): 674-678, 2010. PMID: 20395795. DOI: 10.1097/SAP.0b013e3181dba892

46 Nahabedian MY: Acellular dermal matrices in primary breast reconstruction: principles, concepts, and indications. Plast Reconstr Surg 130(5 Suppl 2): 44S-53S, 2012. PMID: 23096984. DOI: $10.1097 / \mathrm{PRS} .0 \mathrm{~b} 013 \mathrm{e} 31825 \mathrm{f} 2215$

47 Lin KY, Blechman AB and Brenin DR: Implant-based, two-stage breast reconstruction in the setting of radiation injury: an outcome study. Plast Reconstr Surg 129(4): 817-823, 2012. PMID: 22456353. DOI: 10.1097/PRS.0b013e31824421d0

48 Paepke S, Klein E, Ettl J, Niemeyer M, Bronger H, Paepke D and Kiechle M: Nippel-sparende subkutane Mastektomie (NSSM) als Reduktionsplastik mit deepithelsiertem fasziokutanem Flap, subpektoraler Implanteinlage und Titan-PolypropylennetzInterponat. Senologie - Zeitschrift für Mammadiagnostik und therapie 8(04): 210-214, 2017. DOI: 10.1055/s-0031-1283837

49 Berger MD, Gerber B, Arn K, Senn O, Schanz U and Stussi G: Significant reduction of red blood cell transfusion requirements by changing from a double-unit to a single-unit transfusion policy in patients receiving intensive chemotherapy or stem cell transplantation. Haematologica 97(1): 116-122, 2012. PMID: 21933858. DOI: 10.3324/haematol.2011.047035

50 Karsten MM, Enders S, Knabl J, Kirn V, Düwell P, Rack B, Blohmer JU, Mayr D and Dian D: Biologic meshes and synthetic meshes in cancer patients: a double-edged sword: differences in production of IL- 6 and IL-12 caused by acellular dermal matrices in human immune cells. Arch Gynecol Obstet 297(5): 1265-1270, 2018. PMID: 29417284. DOI: 10.1007/s00404-018-4710-z

51 Orenstein SB, Qiao Y, Kaur M, Klueh U, Kreutzer DL and Novitsky YW: Human monocyte activation by biologic and biodegradable meshes in vitro. Surg Endosc 24(4): 805-811, 2010. PMID: 19697086. DOI: 10.1007/s00464-009-0664-3

52 Loo YL, Kamalathevan P, Ooi PS and Mosahebi A: Comparing the outcome of different biologically derived acellular dermal matrices in implant-based immediate breast reconstruction: A meta-analysis of the literatures. Plast Reconstr Surg Glob Open 6(3): e1701, 2018. PMID: 29707460. DOI: 10.1097/GOX.0000000000001701

Received June 19, 2021

Revised July 11, 2021

Accepted July 15, 2021 